\title{
THE INTERACTIVITY OF ICT TOOLS
}

\author{
Michal Kortan*, Jihočeská Univerzita \\ Miloš Prokýšek, Jihočeská Univerzita
}

Přijato: 24. 9. 2015 / Akceptováno: 13. 10. 2015

Typ článku: Teoretická studie

DOI: $10.5507 /$ jtie.2015.015

Abstract: This article deals with the concept of interactivity which, in course of time, became overused, not only in terms of information systems. Thus, the thesis also discusses the unclear interpretation of interactivity and aims to express more apt definition. The interactivity is analyzed across various fields, which further provides a basis for the establishment of unbiased model called classification frame defining a degree of interactivity of specified complex systems.

Key words: Classification frame, complex system, HCI, interactivity

\section{INTERAKTIVITA ICT ZAŘÍZENÍ}

Resumé: Předmětem zkoumání tohoto článku je koncept interaktivity, jež se postupem času stal naduživaným a to nejen z hlediska informačních systémů. Článek se tedy mimo jiné věnuje problematice nejasného vymezení termínu interaktivita a pokouši se přspět $k$ jeho pregnantnějši definici. V rámci článku je analyticky zkoumána interaktivita napřič různými obory a na základè této analýzy je stanoven objektivní model tzv. klasifikační rámec, určujici míru interaktivity stanovených komplexnich systémů.

Klíčová slova: Klasifikační rámec, komplexní systém, HCI, interaktivita

\footnotetext{
5. This journal was approved on 2015-04-23 according to ERIH PLUS criteria for inclusion.

*Autor pro korespondenci: michalkortan@ seznam.cz
} 


\section{1 Úvod}

Předmětem zkoumání tohoto článku je koncept interaktivity, jež se postupem času stal nadužívaným a to nejen z hlediska informačních systémů. Článek se tedy mimo jiné věnuje problematice nejasného vymezení termínu interaktivita a pokouší se přispět k jeho pregnantnější definici. Nejednoznačnost interaktivity má tudíž negativní důsledky pro vývoj její teorie a prrípadného vytvoření rámce pro výzkumy (McMillan, a další, 2002) a proto článek zkoumá koncept interaktivity z mnoha pohledů.

Velice důležitý obor $\mathrm{k}$ pochopení samotné definice interaktivity je HCI, kde je chápán jako hraniční s vazbami k informační vědě. HCI zde velmi detailně zkoumá koncového uživatele, kde je uživatel i jeho okolí rovněž zkoumáno informační vědou (Papík, 2001). Interaktivita je obecně považována za charakteristiku nových médií, avšak ne všechna nová média jsou interaktivní. Nová média podle Manoviche (Manovich, 2001) reprezentují konvergenci dvou historicky oddělených trajektorií: výpočetních a mediálních technologií. Manovich dále uvádí, že použiváme-li tyto média, interagujeme s interfejsem samotným. Je tedy důležité porozumět tomu, co je dělá interaktivními a uvědomit si, že interaktivita je pro různé lidi v odlišném kontextu mnohovýznamová.

Dále jsou sestaveny komplexní systémy a podle stanoveného klasifikačního rámce je jim stanovena míra interaktivity.

Již samotná definice pojmu interaktivita, která je ústředním předmětem zkoumání tohoto článku, představuje samostatný výzkumný problém. Vzhledem $\mathrm{k}$ poměrně velkému počtu různých úhlů pohledu, je téměř nemožné nalézt vhodnou univerzální definici tohoto termínu. Je však možné na něj nahlížet mnoha pohledy.

\section{Interaktivita komunikace}

Interaktivita se z pohledu komunikačních technologií objevuje $\mathrm{v}$ tzv. modelech komunikace, jež poukazují na konceptuální model používaný k vysvětlení komunikačního procesu. Existují tři typy komunikačních modelů: Lineární, Interaktivní a Transakční model. Autoři nejstaršího lineárního modelu komunikace jsou Shannon a Weaver, jež v roce 1949 přišli s tímto označením. Použili zde dnes již běžný koncept poslání a obdržení zprávy nebo přenesení informace z odesílatele na př́iemce. Hlavním problémem u lineární komunikace je chápání komunikace jako jednosměrného procesu, kde mluvčí jenom mluví, ale nikdy neposlouchá. Stejně jako posluchač jen poslouchá, ale nikdy nemluví nebo neposílá zprávy (Weaver, 1949). Později Schramm (Schramm, 1954), jenž používal k popisu komunikace komponenty (zpráva, zdroj, cíl, odesílatel, příjemce či kanál), došel k závěru, že komunikace je sociální interakce, kde alespoň dva interagující prostředky sdílejí společné příznaky a společný soubor sémiotických pravidel. V práci Woodové (Wood, 2009), jež navazovala na práci Schramma, vznikl interaktivní model, který ukazuje, že prŕijemce nebo posluchač poskytuje zpětnou vazbu odesílateli nebo mluvčímu. Jak mluvčí, tak posluchač se střídají v mluvení a poslouchání navzájem přičemž je zpětná vazba podávána verbálně i neverbálně zároveň.

V polovině osmdesátých let Rafaeli (Rafaeli, 1988) definoval interaktivitu jako přirozenou vlastnost komunikace tváŕí v tvář (face-to-face, F2F), vyskytující se i ve zprostředkování komunikace. U obousměrných systémů se interaktivita dá chápat jako jedna $\mathrm{z}$ definujících charakteristik, jako je tomu u diskuzních pořadů v rádiu či v televizi. Tyto obousměrné systémy mají, podle Rafaeliho, vlastnosti interaktivity. Rafaeliho definice se zaměřovala na reakci jakožto na měření vjemu médií a reakci na odpovědi obdržené uživatelem. Tento koncept používal progresivní úrovně v jeho kontinuu a to: 1) 
Dvoucestná komunikace probíhala $\mathrm{v}$ př́ípadě, byly-li zprávy doručovány oběma směry. 2) Reaktivní komunikace vyžadovala reakci pozdějších zpráv na předchozí zprávu. 3) Plná interaktivita vyžadovala odpověd' pozdější zprávy na sekvenci předchozích zpráv.

\section{Informačně-technologické aspekty interaktivity}

Na počátku technologického pojetí interaktivity stojí Alan Turing, jako představitel standartu porovnávání tzv. konverzačního ideálu, prezentující pojem pro „lepši“ média, který určitým způsobem emulují způsob, jímž lidé konverzují (Turing, 1950). Dále zavedl pojmy, jako jsou: Turingův test, jenž je používán do dnešní doby jako test umělé inteligence založený na konverzačním modelu mezi člověkem a zkoumaným systémem, či symbióza člověk-počítač. Na bázi matematiky, vědeckých poznatků a technologické proveditelnosti, popsal komunikaci člověk-počítač, kde je téměř nemožné rozeznat jednoho od druhého.

Brecht převedl jeho teorii na média a rozeznával sociální a politické dopady komunikace člověk-člověk, jež se tvarují do stále dokonalejších mediálních strojü. Zatímco je tedy pro Turinga interakce proces probíhající mezi člověkem a strojem, pro Brechta je to komunikace tvář́ v tvár, potažmo mezi autorem a recipientem. Definice interaktivity jako konverzačního ideálu se ukázalo atraktivní, ale problematické, jak z hlediska kulturního, tak časového konceptu. Na Turinga a Brechta poukazuje Daniels, teoretik zabývající se interaktivitou v kontextu umění, jenž je označuje za jedny $\mathrm{z}$ prvních zakladatelů technologického a ideologistického pojetí interaktivity (Deiter, 2000). Podle Danielse jsou v př́stupu k interaktivitě klíčová dvě jména, jimiž jsou Cage a Gates. Cage a jeho koncept, $v$ němž umožnuje interaktivita prímo zasahovat do struktury díla a Gates, jenž pouze stanovil hranice, ve kterých se uživatel může pohybovat.

K definici interaktivity prrispívá, podle McLaughlinové (McLaughlin, 1984), problematika odezvy. Rozděluje zde mezi interaktivní, reaktivní a neinteraktivní (dvoucestnou) komunikační posloupností. Interaktivní a reaktivní se od neinteraktivní komunikace liší čistě v požadavku na dva komponenty informačního přenosového modelu a to odesílatele a př́jemce na jejich zaměnitelnost s každou následující zprávou. Kompletní absence interakce je podle ní označena jako nárazová a nesouvislá komunikace. Rozdíl mezi interaktivní a reaktivní komunikací závisí na povaze odpovědi. Interaktivní se komunikace stává v momentě, kdy si mezi sebou komunikující strany navzájem odpoví. Ale samotný obsah odpovědi může mít jednu ze dvou formulací: regulární, tzn. odpověd'-reakce na předchozí zprávu, nebo odpověd', jež se potvrdí sama před odpovědí. Podmínky pro plnou interaktivitu jsou splněny, pokud pozdější stavy v sekvenci zpráv závisí na reakci v dřívějších transakcích stejně jako př̀i výměně obsahů zpráv. Situace nebo médium tedy zůstává reaktivní, nemá-li pozdější odpověd'. Čili aby komunikace byla reaktivní, vyžaduje doplněk, jenž pozdější zprávy odkáže na ty předchozí nebo s nimi souvisí.

V polovině dvacátého století, se vznikem kybernetických teorií, se interakce definovala jako proces zpětné vazby. Wiener, jenž v roce 1947 vymyslel termín kybernetika, se méně zajímal o interakci mezi lidmi, ale spíše o analogii mezi vlastní organizací lidského organismu a kybernetiky (Wiener, 1988).

Proti tomu byl Cover, jeden z autorů, jež striktně odmítal technologické definice, a tudíž sám překládal definici na textuální podstatu díla. Jako klasické pojetí z technologického hlediska považuje definici od Greenové, jež bere každé mediální 
technologie jako interaktivní, pokud vyžadují aktivní jednání ze strany uživatele, tzv. aktivní zpětnou vazbu. Pokusíme-li se o zobecnění, dojdeme k technicistnímu pojetí interaktivity a k označení HCI (Cover, 2007).

Dále pak existují tři tř̌́dící kritéria, pomocí nichž je systematicky možné popsat pojem interaktivita $\mathrm{z}$ technicistního hlediska. Jsou jimi: 1) Interaktivita $\mathrm{v}$ rámci komunikačního systému. 2) Interaktivita $\mathrm{v}$ rámci produkčního systému (počítačový program). 3) Interaktivita v rámci umístění.

Interaktivita v rámci komunikačního systému (nejjednodušší třídění interaktivního procesu) je model „kdo s kým“, tedy kdo nebo co jsou účastníci interaktivní komunikace (Rafaeli, 1988). Považujeme-li interaktivitu za situaci, kde je alespoň na jedné straně člověk, pak mluvíme o komunikaci člověk-počítač nebo člověk-člověk (Stromer-Galley, 2004). Existují však i vymezení interakce na člověk-dokument, kde dokument není považován jen za text, ale např́klad za webovou stránku, hypertextové linky atd. U tohoto typu interakce však nelze s tímto dokumentem prakticky „komunikovat“ ve smyslu interakčního jednání, ovlivněn je pouze čas př́stupu. Dále pak vztah uživatelsystém nebo uživatel-počítač, jež má mezi uživatelem a počítačem charakter pokročilejší formy interaktivity při možnosti širšího rozsahu aktivních voleb. Právě tyto volby pomocí rozhraní HID ( Human interface device) odlišují tento způsob interakce od předchozího tím, že poskytují zpětnou vazbu uživateli. Interakce člověk-člověk se oproti ostatním liší operacemi v reálném čase (Jensen, 1998).

U interaktivity v rámci produkčního systému je pozornost věnována faktu, zda je interaktivita vytvořena (je produktem) nebo se vyskytuje (je procesem). Tento model je kombinace percepčních a kontextových definic z modelu interaktivity v rámci umístění. Typ interaktivity chápaný jako produkt zahrnuje uživatelem kontrolovanou interakci s obsahem (multimédia, hyperlinky, formy zpětné vazby) a typ interaktivity jako proces souvisí s lidskou interakcí a její zaměření na oblasti jako jsou: reciprocita komunikace, informační výměna a tak podobně (Stromer-Galley, 2004).

\section{Interakce člověk-počítač (HCI)}

Problematika HCI (human-computer interaction neboli interakce mezi člověkem a počítačem), také nazývaná man-machine interaction nebo interfacing, v sobě zahrnuje mnoho oborů a oblastí jako je: počítačová věda, ergonomie, umění, design, psychologie, sociologie či umělá inteligence (Faulkner, 1998). Dále se zabývá tvorbou nových technologií, vylepšování starých či jejich testováním. Pozornost je zde věnována faktorům, jež působí při interakci. $K$ těm nejdůležitějším patří uživatelské rozhraní, na něž jsou kladeny vysoké nároky pro lepší využitelnost. Zahrnuje v sobě vstupní a výstupní zařízení počítače společně se softwarovým nástrojem určeným pro navázání kontaktu s uživatelem. Při tvorbě uživatelského rozhraní se uplatňují poznatky z oblastí psychologie, designu či ergonomie.

Výzkum interaktivity se rozděluje na tři základní oblasti podle účastníků interakce a to na human-to-human, human-to-documents a human-to-system. Každý z těchto typů je používán pro vývoj modelů, jež ilustrují mnoho typů interaktivity (Livingstone, 2006). Počátky jsou podle Shakela v tzv. humanitních disciplínách, kterými myslí např́klad filozofii, fyziologii, medicínu či psychologii.

Königová ve vztahu ke konstrukci informačního systému př́ímo deklaruje, že uživatel je v podstatě centrálním a určujícím činitelem celého informačního systému. Bez respektování potřeb konkrétních uživatelů systém pracuje do jisté míry naprázdno a z 
ekonomického hlediska neefektivně (Königová, 1984). Velice důležité aspekty v navrhování HCI, jsou tzv. tři úrovně uživatelské aktivity, jež zahrnují fyzickou, kognitivní a afektivní úroveň. Fyzický aspekt (Chapanis, 1965) určuje mechaniku interakce mezi člověkem a počítačem, zatímco kognitivní aspekt (Norman, 1986) se vypořádává s pochopením systému uživatelem, jež s ním interaguje. Afektivní aspekt se snaží nejen o to udělat $\mathrm{z}$ interaktivity potěšující zkušenost pro uživatele, ale také ho ovlivnit v pokračování používání stroje změnou uživatelova postoje (Picard, 1997). Soustředění se na čtení knihy je většinou postup fyzického aspektu interakce, jež poukazuje na to, jak rozdílné metody interakce mohou být kombinovány (multi-modální interakce) a jak může být každá metoda zlepšena (inteligentní interakce) aby poskytovala lepší a jednodušší uživatelské prostředí pro uživatele. Existující fyzické technologie můžou být, podle HCI, kategorizovány podle smyslů, pro které byly sestrojeny. Tato zařízení se v podstatě spoléhají na tři lidské smysly: zrak, sluch a hmat (Te'eni Carey and Zhang, 2007). Jako jeden z prostř̌edníkủ k ovládání jednotlivých systémů těmito smysly nám slouží Graphical User Interface (dále pak GUI), což je speciální typ uživatelského rozhraní (tzv. rozhraní s př́ímou manipulací). Mezi další faktory se řadí: 1) uživatelská přívětivost - navrhnutí systému tak, aby byla práce s ním co nejsnazší 2) použitelnost je-li splněna, je pro uživatele snadné s rozhraním pracovat.

S daným termínem úzce souvisí funkcionalita systému (Shneiderman and Plaisant, 2004), jež je definována jako sada akcí poskytovaných uživateli či použitelnost systému, což je rozsah a stupeň efektivnosti a dostatečnosti pro dosažení uživatelových cílů (Nielsen, 1994). Soustředíme-li se na vlivy a okolnosti ovládání a ř́zení IS, pak tyto systémy lze rozdělit a seřadit vzestupně do jednotlivých stupňů interaktivity (Schulmeister, 2001): 1) automatický systém (nezasahování do běhu systému) 2) změna reprezentace dat (volba reprezentace dat uživatelem $v$ rámci jednoho programu) 3) výběr připraveného nástroje 4) modifikace parametrů aplikace (modifikace chování aplikace pomocí zadání vstupních parametrů) 5) plná interakce (konstrukce nových objektů či ovlivnění algoritmu zpracování dat uživatelem) 6) plná interakce se zpětnou vazbou (plná kontrola nad aplikací se zpětnou vazbou). Nástroji zde rozumíme programové komponenty a zařízeními jsou př́slušná vstupní a výstupní zařízení.

$\mathrm{Z}$ hlediska interakce se systémem v rámci vstupních zařízení, lze hovořit o klávesnici jako o základním komunikačním zařízení. Vyšším stupněm je pak užití polohovacího zařízení (počítačové myši), pomocí něhož lze předat grafické sdělení. Další vstupní zařízení může být dotyková obrazovka, jež funguje na principu dotyku prstu či ovládání pomocí gest např́iklad u Wii od Nintenda nebo Kinect od Microsoftu. Vstupní zařízení obvykle fungují na bázi spínače (klávesnice), čili lineárního (jednorozměrného) vstupu či pozičního zařízení (počítačová myš, dotykové panely...) a jejich jednorozměrný vstup (pozice $\mathrm{X}$ a Y) s dvojrozměrným zobrazením (monitor). Výstupní zařízení může být jakékoliv vizuální čí tiskové zařízení. (Greenstein, 1997). HCI se dělí podle počtu a rozmanitosti jeho vstupů a výstupů, jimiž jsou komunikační kanály zpř́stupňující uživateli možnost interagovat $\mathrm{s}$ počítačem skrze dané rozhraní. Každý $\mathrm{z}$ těchto rozdílných a nezávislých kanálů se nazývá modalita. $Z$ toho vycházejí pojmy unimodální (systém založený na jedné modalitě) a multimodální (systém založený na kombinaci modalit). Modality mohou být rozděleny do tř́ následujících kategorií: vizuální, sluchové a senzorové (Fakhreddine Karray, 2008). 


\section{Modalita HCI interakce}

Vizuálně založené HCI je pravděpodobně nejrozšiřenější v oblasti výzkumu HCI, kde je zkoumána: analýza výrazu tváře, rozeznávání pohybu těla, rozpoznávání gest či mapování pohybu očí. Těžištěm zájmů této oblasti je rozpoznávání pohybu těla (Gavrila, 1999), (Cai, 1999) a gest (Huang, 1999), jež se používá převážně pro přímou interakci. Kdežto za nepř́mou interakci se považuje mapování pohybu očí, jež je nejvíce používané pro lepší porozumění uživatelově pozornosti (Jacob, 2000). Typy modality: Vizuální HCI se pokouší asistovat nebo dokonce nahradit ostatní typy interakce (sluchové, senzorové). $\mathrm{Na}$ sluchu založená interakce mezi počítačem a člověkem se zabývá informacemi získanými rozdílnými zvukovými signály, jež jsou v některých př́padech i unikátní. Stejně jako u vizuálně založené HCI, i zde je výzkumná oblast rozdělena na několik sekcí: rozpoznání hlasu, rozpoznání mluvčího, analýza pocitů, analýza lidských zvuků (pláč, smích...) a hudební interakce. Dochází zde k analýze a následné integraci (v podobě zvukových signálů) lidských emocí do inteligentní HCI (M. Schröder, 2006). Sekce senzorově založených HCI je kombinací různých oblastí s širokým spektrem použití. Navzdory širokému spektru použití, je v tomto typu HCI vždy použit fyzický senzor, používaný $\mathrm{k}$ interakci mezi zařízením a uživatelem. Tyto senzory jsou např́íklad: interakce na bázi pera (S.L. Oviatt, 2000), počítačová myš a klávesnice, joystick, senzory pro sledování pohybu, hmatové, tlakové či čichové a chutové senzory (Fakhreddine Karray, 2008).

\section{Klasifikační rámec}

$\mathrm{Na}$ základě předešlé teoretické části článku byl sestaven klasifikační rámec pro určení míry interaktivity komplexních systémů. Tyto systémy jsou kombinací níže zmíněných zařízení (např. $\mathrm{PC}+$ počítačová myš $+\mathrm{SW}$ ). Pro zařazení těchto systémů do klasifikačního rámce, budou tyto systémy prezentovány na vhodných př́íladech zobrazujících závislost $\mathrm{SW}$ a $\mathrm{HW}$ na stanovení míry interaktivity. V rámci provedené analýzy pojmu interaktivita lze vypozorovat čtveřici fundamentálních elementů, o které se opírá vytvořený klasifikační rámec. Prvním faktorem, jednoznačně ovlivňujícím míru interaktivity, jsou jednotlivé smysly využívané pro komunikaci mezi zařízením a uživatelem. Tedy čím více smyslů při ovládání daného systému používáme, tím vy̌šší míry interaktivity systém dosahuje. Modalita, jakožto druhý faktor, bude rozdělena na vstupní a výstupní s třemi parametry: vizuální, sluchová a senzorová. Tyto tři faktory nahlížejí na jednotlivé systémy z hardwarového pohledu. Dalším faktorem určujícím interaktivitu systému je produktivita. Tento faktor je zaměřen na možnosti softwaru, kterých může daný systém dosahovat. Prvního stupně dosáhne ten systém, jenž dovoluje uživateli pouze pasivní kontakt bez možnosti jakéhokoliv zásahu či úpravy. Zařízení dosahující druhého stupně produktivity umožnuje navíc možnost úpravy a u třetího stupně může uživatel pomocí daných zařízení vytvářet nový obsah. Jako poslední a zároveň i nejdůležitější faktor vyplývající ze samotné podstaty interaktivity je vzájemné ovlivňování. Tento faktor bude vypočitán z tabulky obsahující dva kanály (ř́dící a informační), jež určují, jakým způsobem musí uživatel ovlivnit systém nebo systém uživatele $\mathrm{k}$ dosažení požadované informace. Těmito kanály pak proudí řídící či informační zprávy posílané od uživatele do systému či naopak. Jako ilustrativní př́ílad tohoto faktoru je možné uvést jednoduchou softwarovou kalkulačku. Zde člověk podává informace kalkulačce a ta mu vrací zpět informaci o výsledku. Tento software tudíž dosahuje $50 \%$ z celkového faktoru vzájemného ovlivňování. 


\begin{tabular}{|l|l|l|}
\hline Vzájemné ovlivňování & Řídící & Informační \\
\hline Člověk-počítač & $\mathrm{Ne}$ & Ano \\
\hline Počítač-člověk & $\mathrm{Ne}$ & Ano \\
\hline
\end{tabular}

Tab 1:Vzájemné ovlivňování.

Jak je z uvedeného príkladu zrejmé, bude tento faktor dosahovat 3 stupňů: prvního za $50 \%$ naplnění tohoto faktoru, druhého za $75 \%$ a nejvyššího za $100 \%$. U tohoto faktoru platí, že jakýkoliv systém nedosahující $50 \%$ nelze považovat za interaktivní.

Kritéria klasifikačního rámce (všechny dosahují max. hodnoty 3): Vzájemné ovlivňovaní, Smysly, Produktivita, Modalita- vstup, Modalita- výstup.

Typickým a zároveň nejpoužívanějším př́íkladem komplexního systému je kombinace PC, klávesnice, myši, sluchátek a mikrofonu (modře znázorněný). Pro dosažení nejvyšší možné míry interaktivity toho systému je tento systém demonstrován na softwaru, jež má potenciál pro jeho maximální využití. Z tohoto důvodu je vybrána počítačová budovatelská strategická hra (např. Anno 1404). Jedná se o systém využívající zraku, sluchu a hmatu, jež jako vstupní informaci využívá stisku klávesy, stisku a pozici myši či možnosti komunikace pomocí mikrofonu. Výstupem vrací zobrazená data na monitoru a audio signál pomocí sluchátek. Podíváme-li se na tento systém z hlediska produktivity, zjistíme, že zde máme možnost tvorby nového obsahu. Při zkoumání vzájemného ovlivňování zjistíme, že člověk na hru působí jak řídícími (,postav budovu“) tak informačními (,,postav budovu na tomto místě“) zprávami. Hra nás informuje např. o postupu stavby a ovlivňuje chování uživatele. Například, je-li populační limit vyšší než počet míst $\mathrm{k}$ bydlení pak uživatel musí reagovat postavením nových domů. V následujícím klasifikačním rámci je uvedena míra interaktivity dvou dalších zařízení, jimiž jsou: PC v kombinaci sklávesnicí a myší se stejným softwarem (červeně znázorněný) a výše popsaný komplexní systém v kombinaci se softwarovou kalkulačkou (zeleně znázorněný). Tyto systémy jsou uvedeny jako ukázka, jak hardware $\mathrm{v}$ kombinaci s různým softwarem působí na míru interaktivity. Tyto príklady lze demonstrovat na všech dále zmíněních systémech, a tudíž bude dále uvedena jen maximální míra interaktivity daných systémů.

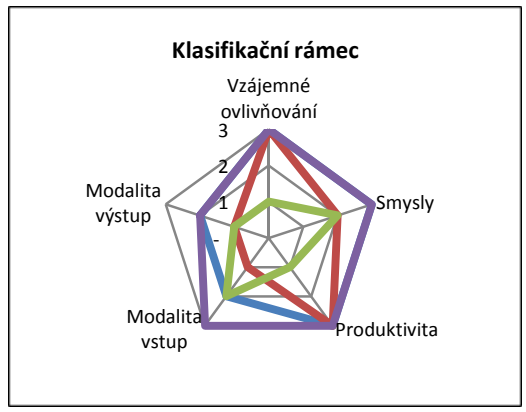

Obr 1: Znázorněni komplexnich systémů. 
Za zmínku zde stojí Leap Motion, jež lze použít jako náhradu počítačové myši a tudíž zvýší úroveň modality na vstupu (fialově znázorněný).

\section{Závěr}

Tento článek usiloval o uchopení fenoménu interaktivity z hlediska informačních a komunikačních technologií a to především na interaktivitu komunikace člověk-počítač. V úvodní části článku byla pozornost věnována především samotné definici pojmu interaktivita a to multidisciplinárním způsobem. Za použití analyticko-syntetických metod článek usiloval především o nalezení odpovědi na otázku, jaká jsou obecná specifika systémů, které lze označit jako interaktivní?

Na základě provedené analýzy lze říci, že za potenciálně interaktivní technologii lze považovat takový systém, u kterého dochází ke vzájemné komunikaci mezi člověkem a strojem, přičemž lze specifikovat tři základní aspekty této komunikace: směr komunikace, časové vnímání a uživatelská kontrola. Interaktivní systém musí tedy splňovat kritérium oboustranné komunikace.

V následující kapitole se článek zaměřuje na chápání interaktivity v prostředí počítačových technologií konkrétně tedy HCI. Z této kapitoly byly pomocí induktivně deduktivní metod stanoveny jednotlivé faktory klasifikačního rámce a to modalita vstupu, výstupu, počet zapojených smyslů, aspekt produktivity a vzájemné ovlivňování aktérů komunikace. Pomocí těchto faktorů lze najít odpověd' na otázku, čím se liší interaktivita jednotlivých zařízení? V následující kapitole bylo uvedeno sestavení komplexních systémů, na kterých bylo demonstrováno jak kombinace hardwarového či softwarového vybavení působí na míru interaktivity.

\section{Literatura}

Cai, J. A. (1999). Human motion analysis: a review. Computer Vision and Image Understanding $(73)$.

Chapanis, A. (1965). Man Machine Engineering. Belmont: Wadsworth.

Cover, R. (2007). Inter/aktivní publikum: Interaktivní média, narativní kontrola a revize dějin publika. Victoria University of Wellington, New Zealand: Sage.

Deiter, D. (2000). Media Art Interaction: The '80s and '90s in Germany. Wien: Springer. Fakhreddine Karray, M. A. (2008). Human-Computer Interaction: Overview on State of the Art . INTERNATIONAL JOURNAL ON SMART SENSING AND INTELLIGENT SYSTEMS, vol. 1(no. 1).

Faulkner, C. (1998). The essence of human-computer interaction. New York: Prentice Hall.

Gavrila, D. (1999). The visual analysis of human movement: a survey. Computer Vision and Image Understanding(73).

Greenstein, J. (1997). Pointing devices. Amsterdam: Elsevier Science.

Huang, Y. W. (1999). Vision-based gesture recognition: a review. Berlin/Heidelberg :

Springer-Verlag.

Jacob, L. S. (2000). Evaluation of eye gaze interaction. Conference of Human-Factors in Computing Systems.

Jensen, J. F. (1998). Interactivity, Tracking a New Concept in Media and Communication Studies. NORDICOM Review. 
Königová, M. (1984). Teorie systémù védeckých, technických a ekonomických informací. Praha: ÚVTEI.

Livingstone, L. A. (2006). Handbook of New Media: Student Edition. Sage.

M. Schröder, D. H. (2006). Perception of non-verbal emotional listener feedback. Speech Prosody 2006.

McLaughlin, M. L. (1984). Conversation: How talk is organized. Beverly Hills, CA:

Sage.

Nielsen, J. (1994). Usability Engineering. San Francisco : Morgan Kaufman.

Norman, D. (1986). Cognitive Engineering. Hillsdale: Lawrence Erlbaum.

Picard, R. (1997). Affective Computing. Cambridge: MIT Press.

Rafaeli, S. (1988). Interactivity: From New Media to Communication. Beverly Hills, CA: Sage.

S.L. Oviatt, P. C. (2000). "Designing the user interface for multimodal speech and penbased gesture applications: state-of-the-art systems and future research directions.

Human-Computer Interaction(15).

Schramm, W. (1954). How communication works. Urbana, Illinois: University of Illinois Press.

Schulmeister, R. (2001). Taxonomy of Multimedia Component Interactvity: A

Contribution To The Current Metadata Debate. Hamburg.

Shneiderman and Plaisant, B. S. (2004). Designing the User Interface: Strategies for Effective Human-Computer Interaction (4th edition). Boston: Pearson/Addison-Wesley. Stromer-Galley. (2004). Interactivity-as-Product and Interactivity-as-Proces. Routledge: Taylor\&Francis group.

Te'eni Carey and Zhang, D. T. (2007). Human Computer Interaction: Developing Effective Organizational Information Systems. Hoboken: John Wiley \& Sons.

Turing, A. M. (1950). Computing machinery and inteligence. Mind, 59, 433-460.

Weaver, C. E. (1949). The mathematical theory of communication. Urbana, Illinois: University of Illinois Press.

Wiener, N. (1988). The human use of human beings. New York: Da Capo Press. Wood, J. T. (2009). Communication in our lives (4th edition). Belmont, CA: ThomsonWadsworth. 